Jurnal Kajian Gender dan Anak

Vol. 02 No. 2 Desember 2018

e-ISSN : 2549-6352, p-ISSN: 2549-6344

Web: jurnal.iain-padangsidimpuan.ac.id/index.php/JurnalGender

\title{
PERSEPSI ORANGTUA TENTANG PENDIDIKAN TINGGI BAGI ANAK PEREMPUAN DI DESA SIMATORKIS KEC. DOLOK KAB. PADANGLAWAS UTARA
}

\author{
SAWALUDDIN SIREGAR \\ IAIN Padangsidimpuan \\ lisyasiregar@gmail.com
}

\begin{abstract}
Abstrak: Kajian ini merupakan upaya untuk mengetahui persepsi orangtua tentang pendidikan tinggi bagi anak perempuan di desa Simatorkis Kec. Dolok Kab. Padanglawas Utara. Adapun pertanyaan yang ingin dikejar penulis adalah persepsi orang tua dalam memberikan kesempatan pendidikan tinggi kepada anak perempuannya. Setelah dilakukan penelitian secara sistematik dapat diketahui bahwa persepsi orangtua tentang pendidikan tinggi bagi anak perempuannya sebagai berikut : Pendidikan tinggi itu penting bagi anak prempuan agar bisa bersaing dengan jaman yang semakin modern, menjadi orang berhasil, berilmu dan ternama dalam masyarakat yang akan menjadi kebanggaan. Faktor yang menghambat pendidikan tinggi bagi anak perempuan di desa Simatorkis adalah sosial budaya, keadaan ekonomi, faktor psikologis. Alasan dan pertimbangan orangtua memberikan kesempatan pendidikan tinggi bagi anak perempuanya keinginan untuk merubah nasib, dan kesadaran orang tua yang berpandangan bahwa pendidikan tinggi itu penting bagi anak laki-laki maupun perempuan tanpa harus ada pembedaan.
\end{abstract}

Kata Kunci : Kesetaraan Gender, Perubahan sosial budaya, Pendidikan tinggi, Padanglawas Utara
Abstract: This study is an attempt to find out the perceptions of parents about higher education for girls in the village of Simatorkis, Kec. Dolok Kab. Padanglawas North. The question the author wants to pursue is the perception of parents in providing higher education opportunities to their daughters. After systematic research, it can be seen that parents' perceptions of higher education for their daughters are as follows: Higher education is important for girls to be able to compete with an increasingly modern era, to be successful people, knowledgeable and wellknown in society that will become proud. Factors that hinder higher education for girls in Simatorkis village are social culture, economic conditions, psychological factors. Reasons and considerations of parents providing opportunities for higher education for their children is the desire to change their destiny, and awareness of parents who think that higher education is important for boys and girls without having to make a difference.

Keywords: Gender Equality, Socio-cultural Change, Higher Education, Padanglawas North

\section{A. Pendahuluan}

Pendidikan pada masa sekarang ini seharusnya tidak lagi memandang gender, apakah dia kaum perempuan ataupun laki-laki. Memiliki pendidikan yang tinggi bagi seorang perempuan mungkin 
bukan hal yang mudah untuk dicapai apalagi jika dikaitkan dengan kodrat perempuan yang kelak akan menjadi ibu rumah tangga. Pendidikan tinggi yang dimaksud ini juga bukan hanya berbicara tentang pendidikan formal yang kita peroleh di sekolah atau di universitas, tetapi bagaimana seorang perempuan memiliki pengetahuan yang luas dan berusaha meraih pendidikan yang lebih baik itu juga menjadi catatan penting. Karena sejatinya proses merupakan hal yang paling penting dari hasil yang secara kasat mata selalu terlihat.

Secara histories-kultural, kaum perempuan telah diperlakukan secara diskriminatif, yang tercermin pada sikap dan perlakuan orang tua atau keluarga terhadap anak-anak perempuan dan anak laki-laki. Anak laki-laki diberi kesempatan lebih untuk menempuh ke jenjang pendidikan tinggi dibandingkan perempuan. Pada umumnya anak lakilaki lebih diutamakan daripada anak perempuan, dalam banyak hal seperi pendidikan, peluang dan kesempatan untuk beraktualisasi diri. Orang tua, keluarga, dan masyarakat sudah mempunyai pola pikir dan pola sikap diskriminatif dalam perlakuan terhadap anak laki-laki dan perempuan. (Offorma, 2015)lihat juga (Pendidikan, t.t.)

Orang tua yang memutuskan untuk memberikan kesempatan pendidikan tinggi kepada anak laki-laki karena dipandang sebagai pencari nafkah dalam keluarga. Padahal pada zaman sekarang tidak hanya laki-laki yang membutuhkan pendidikan tinggi karena sekarang banyak anak perempuan yang mampu bekerja disektor publik dan membutuhkan pendidikan yang memadai. Sekarang ini banyak anak perempuan yang membantu untuk memenuhi kebutuhan keluarga.

Selain pertimbangan tersebut ada juga faktor keadaan ekonomi masyarakat Simatorkis bisa dikatakan ekonomi menengah kebawah. Masyarakat mempunyai mata pencaharian sebagai petani, buruh tani, pedagang, karyawan swasta. Dengan keadaan ekonomi yang seperti itu 
akan semakin sulit untuk memberikan kesempatan anak memperoleh pendidikan tinggi.

Berdasarkan data di desa Simatorkis dalam 5 tahun terakhir, bahwa hanya sebahagian kecil yang memberikan kesempatan untuk memperoleh pendidikan tinggi. Yakni orangtua yang memiliki kesadaran dan orangtua yang mempunyai tingkat ekonomi mampu. Dalam mengambil keputusan tersebut, orang tua lebih mempertimbangkan keadaan ekonomi sebagai tolok ukur kemampuan dalam memberikan kesempatan yang sama antara anak laki-laki dan perempuan. Penelitian ini dimaksudkan untuk mengetengahkan persepsi orang tua dalam memberikan kesempatan pendidikan tinggi kepada anak perempuannya.

\section{B. Pembahasan}

1. Keberadaan Anak dalam Keluarga

Salah satu tujuan dari sebuah perkawinan adalah diperolehnya seorang keturunan. Pasangan suami istri yang tidak berhasil memperoleh anak atau keturunan dipandang sebagai pasangan yang tidak beruntung, dan akan banyak usaha yang dilakukan agar kelak dikaruniai keturunan. Salah satu diantaranya mengadopsi seorang anak menurut kepercayaan para orangtua, sebagai pemancing untuk bisa memiliki keturunan. Tetapi ketika dikarunia anak selanjutnya yang banyak terjadi adalah adanya pembedaan nilai antara anak lakilaki dan perempuan.

Sebagai generasi penerus keturunan dalam sebuah keluarga. Semejak kecil telah diperkenalkan dengan pranata, aturan, norma, dan nilai-nilai budaya yang berlaku melalui pengasuhan yang diberikan orangtua dalam keluarga. Dengan pola pengasuhan yang diterapkan orang tua ada harapan bahwa anaknya kelak menjadi anak yang 
pintar, bisa diandalkan, berguna serta mempunyai kelakuan yang baik, sehingga dapat menjaga nama baik keluarga.

Keberadaan anak memiliki nilai tersendiri bagi orang tua dalam kehidupan sehari-hari, antara lain bahwa anak menjadi tempat mencurahkan kasih sayang, anak merupakan sumber kebahagiaan keluarga, anak sering dijadikan pertimbangan oleh sepasang suami istri untuk membatalkan keinginannya bercerai, kepada anak nilainilai dalam keluarga disosialisasikan, dan harta kekayaan keluarga diwariskan, dan anak menjadi tempat orang tua menggantungkan berbagai harapan.

Pada masyarakat Simatorkis keberadaan anak dalam keluarga berperan sebagai; 1) bidang kehidupan sosial, anak berperan sebagai penerus keturunan dan sebagai ahli waris. Dalam peranannya sebagai ahli waris, anak tidak semata-mata mewarisi harta peninggalan orang tua (warisan yang bersifat material), akan tetapi juga mewarisi kewajiban adat (warisan yang bersifat immaterial). 2) bidang ekonomi, dapat dilihat dari peranan anak dalam memberikan bantuan yang bernilai ekonomi kepada orang tua. Bantuan tersebut umumnya berupa bantuan tenaga kerja maupun bantuan berupa materi. Bantuan ekonomi dalam bentuk materi, oleh para orang tua diakui sangat penting karena meringankan beban ekonomi rumah tangga. 3) segi psikologis, anak mempunyai nilai positif maupun negatif. Nilai psikologis positif dapat dilihat dari adanya kenyataan yang dialami oleh para orang tua bahwa anak dapat menimbulkan perasaan aman, terjamin, bangga dan puas. Perasaan semacam ini umumnya dialami oleh pasangan suami istri yang telah mempunyai anak laki-laki. Para orang tua merasa puas, aman dan terjamin karena yakin telah ada anak yang diharapkan menggantikan kelak dalam melaksanakan kewajiban adat, di lingkungan kerabat maupun masyarakat. Selain itu, anak juga dirasakan dapat menghibur orang tuanya, memberi 
dorongan untuk lebih semangat bekerja, dan menghangatkan hubungan suami istri. Nilai psikologis yang negatif dapat dilihat dari adanya kenyataan yang dialami oleh beberapa orang tua yang anaknya sering sakit, sehingga anaknya itu menimbulkan perasan khawatir atau was-was. (Ihromi, 2004:. 234-237)

Pada masyarakat Simatorkis nilai pada anak dibedakan dalam berbagai segi seperti religius, sosial, ekonomi, dan psikologis serta pendidikan. Hal tersebut merugikan sekali bagi seorang anak perempuan karena pada akhirnya akan menimbulkan suatu pembedaan dalam berbagai hal seperti pendidikan, karena anak lakilaki akan lebih diutamakan. Selain nilai yang dibedakan peran juga dibedakan antara anak laki-laki dan perempuan. Perbedaan peran laki-laki dan perempuan memang sudah tidak dapat dipungkiri dan menganggap hal itu biasa dan menjadi satu hal yang lumrah terjadi dan memang semestinya seperti itu.(Incing dkk., 2013)

Menurut Ihromi, pria diharapkan peran yang instrumental yaitu berorientasi pada pekerjaan untuk memperoleh nafkah (task oriented), sedang wanita harus melakukan peran yang bersifat ekspresif, yaitu berorientasi pada emosi manusia serta hubungannya dengan orang lain. Oleh karena itu anak laki-laki disosialisasikan untuk menjadi lebih aktif dan tegas, sedang anak perempuan lebih pasif dan tergantung. Hal ini disebabkan pria harus bersaing dalam masyarakat yang bekerja, sedang wanita menjadi istri dan ibu dalam keluarganya.

Hasil pengamatan penulis dilapangan perbedaan perlakuan antara laki-laki dan perempuan yang terjadi dalam masyarakat desa Simatorkis adalah disebabkan oleh budaya yang ada dalam masyarakat, yaitu budaya patriarki yang lebih mengutamakan lakilaki dalam berbagai hal. Peran gender yang dihasilkan oleh konstruksi 
budaya yang ada dalam masyarakat melekat erat di berbagai kehidupannya, sehingga perempuan merasa bahwa apa yang dialaminya saat ini memang sudah menjadi ketentuan yang harus diterima dengan baik. Perempuan sendiri tidak merasa tertindas dengan adanya diskriminasi yang dialaminya. Hal ini sejalan dengan apa yang dikemukakan oleh feminisme liberalis yang menyatakan, bahwa ketertindasan perempuan itu disebabkan oleh dirinya sendiri. Perempuan itu tidak pernah merasa diperlakukan tidak adil, sehingga mereka tidak harus melakukan perlawanan atau usaha apapun.

Prempuan desa Simatorkis merasa tidak mengalami penindasan dan mereka tidak memiliki usaha untuk terlepas dari keadaan yang sangat merugikan mereka tersebut. Hal ini disebabkan oleh budaya masyarakat yang selalu mengutamakan laki-laki dalam banyak hal dibandingkan perempuan. Perempuan pun menyambut baik hal tersebut, sehingga apapun yang diputuskan oleh laki-laki menjadi mutlak. Kenyataan tersebut tentunya menjadikan perempuan terus bergantung pada laki-laki, sehingga perempuan menjadi terpinggirkan.

Kenyataan yang lebih mengutamakan laki-laki daripada perempuan di desa Simatorkis dalam pendidikan tinggi menyebabkan perempuan memiliki pendidikan yang rendah. Rendahnya pendidikan perempuan akan berdampak buruk pada kehidupannya sendiri. Pemiskinan (marjinalisasi) perempuan ini terjadi karena rendahnya pendidikan yang dimiliki perempuan. Oleh Karena itu, perempuan sendiri harus memiliki keinginan yang kuat untuk memperoleh dan memperjuangkan haknya untuk mencapai taraf hidup yang lebih baik. Apabila perempuan memiliki pendidikan yang cukup tinggi, ia akan mampu memperoleh pekerjaan yang baik dan dapat meningkatkan taraf hidupnya, bahkan keluarganya. Perempuan akan lebih mandiri 
dan tidak bergantung pada laki-laki, sehingga berbagai tindak kekerasan dapat diatasi dengan baik. (Khayati, t.t: 1-21)

Budaya patriakal-dominasi laki-laki-memang tidak mudah dihilangkan. Laki-laki dan perempuan memang berbeda, tapi tidak perlu dibeda-bedakan. Kalau disadari ada banyak hal yang membuat masyarakat terjebak dalam budaya patriarki, contoh sederhana saja, bayi laki-laki biasa dipakaikan sesuatu yang bernuansa merah dan bayi perempuan dipakaikan sesuatu yang bernuansa pink. Apabila melihat laki-laki memakai baju pink atau ada laki-laki senang dengan warna pink itu akan menjadi satu hal yang aneh dan dianggap tidak wajar karena warna pink itu dianggap milik perempuan.

Ada hal lain yang sering dilakukan namun lepas dari kesadaran. Masyarakat membedakan pekerjaan laki-laki dan perempuan. Seperti pelajaran bahasa Indonesia yang diajarkan di Sekolah Dasar seperti: Hendra bermain di halaman dan Tuti membantu ibu di dapur. Atau Ibu membeli ikan ke pasar dan Ayah pergi ke kantor. Penggalan kalimat itu rasanya sudah melekat dalam kepala dan itu dijadikan 'referensi' bahwa di situlah perempuan harus di tempatkan. Perempuan berada di ruang domestik dan laki-laki di ruang publik, semua ini diterapkan dalam kehidupan sehari-hati.

Anak-anak perempuan diajak membantu di dapur sedangkan anak laki-laki sibuk bermain. Anak laki-laki bermain mobil-mobilan, sedangkan anak perempuan bermain masak-masakan dan boneka. Hal ini merupakan bentuk diskriminasi yang terjadi dalam keluarga karena kuatnya paham patriakhi, yaitu paham yang mengunggulkan kaum laki-laki. Pola pikir seperti itulah yang membuat anak-anak perempuan makin terpinggirkan, dan ketika dewasa kaum perempuan ini akan sulit untuk menunjukkan kemampuan yang dimilikinya. 
2. Faktor Penghambat Pendidikan Tinggi bagi anak Prempuan di desa Simatorkis

Perilaku masyarakat Simatorkis yang lebih mementingkan pendidikan anak laki-laki ketimbang pendidikan anak perempuan. Ini merupakan fakta adanya kesenjangan gender pada masyarakat Simatorkis bidang pendidikan. Ada beberapa faktor yang menghambat pendidikan anak perempuan di desa Simatorkis antara lain :

a. Sosial budaya

Masyarakat desa Simatorkis pada saat ini masih banyak yang menggunakan acuan budaya paternalis-maskulinitas. Budaya patriarki merupakan segala bentuk dominasi terhadap perempuan, baik berwujud diskriminasi, ketidakadilan maupun tidak diterima, sehalus apapun bentuknya, meskipun orang yang bersangkutan tidak menyebutkannya. Dalam segala bidang kaum laki-laki menjadi pusat dan kaum perempuan dimarginalkan. Moh. Roqib, 2003:. 27)

Budaya ini berisi tentang hubungan laki-laki dan perempuan sebagai pemimpin dan yang dipimpin, pendominasi dan yang didominasi, pelindung dan yang dilindungi, tentu saja hal ini menempatkan perempuan dalam posisi ketidaksetaraan. Kemudian berkembang ditengah masyarakat anggapan bahwa tugas perempuan hanyalah mengurus rumah tangga. Anggapan tersebut berimplikasi kurangnya dorongan keluarga untuk membekali pendidikan anak perempuannya, dengan alasan perempuan pasti kembali ke dapur, sumur, kasur.

Disamping itu berkembang budaya dimasyarakat yaitu ketakutan terhadap keterlambatan perkawinan. Ketakutan tersebut merupakan dampak dari pencitraan sosok laki-laki sebagai pemimpin dalam Islam yang kemudia dikonstruksikan oleh keagamaan yang ada. Anak perempuan sering sampai tidak 
lulus pendidikan tinggi karena banyak gangguan, terutama bila ketemu jodohnya. Orangtua juga merasa risih bila anak perempuannya lama ketemu jodoh. Inilah yang dianggap sering mengganggu karir dan sekolah anak perempuan. (Mansur, 2014: 216)

Akibatnya anak perempuan yang masih berpikiran awam akan lebih memilih menikah daripada menjadi sarjan namun sulit mendapatkan pasangan. Fenomena ini secara otomatis berimplikasi negatif pada usaha peningkatan kualitas dan partisipasi pendidikan anak perempuan. Anggapan seperti itu masih beredar dikalangan masyarakat Simatorkis sehingga menghambat pendidikan anak perempuan.

b. Keadaan Ekonomi

Marginalisasi atau pemiskinan ekonomi terhadap kaum perempuan sudah terjadi di rumah tangga dalam bentuk diskriminasi atas anggota keluarga yang laki-laki dan perempuan. Marginalisasi diperkuat adat istiadat dan tafsir keagamaan (Mansour Fakih, 1996: 14). Misalnya saja, banyak diantara sukusuku di Indonesia dimana kaum perempuannya tidak berhak sama sekali untuk mendapatkan warisan. Sebagian tafsiran agama memberikan hak setengah terhadap kaum perempuan. (Mansour Fakih,dkk, 1996: 61)

Pada umumnya anak perempuan yang mendapatkan kesempatan untuk mengeyam pendidikan adalah mereka yang berasal dari keluarga yang memiliki status sosial ekonomi menegah ke atas, sehingga bagi status ekonomi menengah ke bawah mengalami kesulitan untuk menyekolahkan anak-anaknya. Hal ini menyebabkan pendidikan untuk anak perempuan tidak diprioritaskan akibat status ekonomi tersebut. Hal ini tampak pada 
pada masyarakat Simatorkis, dimana orangtua akan berupaya keras untuk membiayai anak laki-lakinya.

Adanya faktor teologis tentang kepemimpinan laki-laki dalam Islam, mengakibatkan mereka harus diberi bekal sebaikbaiknya. Dapat dikatakan orangtua tidak berusaha untuk mengatasi kesulitan ekonomi anak perempuan atau memperlakukan anak perempuan sebagaimana perlakuan pada anak laki-lakinya. Pandangan gender seperti ini menimbulkan subordinasi terhadap perempuan. Anggapan bahwa perempuan itu irrasional atau emosional sehingga perempuan tidak bisa tampil memimpin, yang berakibat munculnya sikap yang menempatkan perempuan pada posisi yang tidak penting. (Mansour Fakih, 1996: 15)

c. Faktor Psikologis

Para psikolog juga telah memunculkan asumsi bahwa wanita memang berbeda dengan laki-laki. Meraka memiliki kecerdasan yang rendah dan struktur otak yang kurang terspesialisasi, namun kecenderungan emosionalnya melebihi daripada laki laki. Juga digambarkan anak perempuan sebagai makhluk yang kecenderungan psikisnya hanyalah memasak dan memelihara anak.(Kaum \& Millenium, t.t: 225)

Penandaan atau pelabelan seperti itu disebut juga stereotipe. Secara umum stereotipe adalah pelabelan atau penandaan terhadap suatu kelompok tertentu. Celakanya stereotipe selalu merugikan dan menimbulkan ketidakadilan. Salah satu jenis stereotipe itu bersumber dari pandangan gender. Banyak sekali ketidakadilan terhadap jenis kelamin tertentu, umumnya perempuan. Masyarakat memliki anggapan bahwa tugas utama kaum perempuan adalah melayani suami.(Shaukat \& Pell, 2015) 
Maka wajar apabila pendidikan anak perempuan dinomorduakan, karena stereotipe seperti ini yang ditanamkan sejak masa kanak-kanak akan mempengaruhi pemberian kesempatan dan pemanfaatan kesempatan dalam bidang pendidikan kepada anak perempuan. Banyak peraturan pemerintah, aturan keagamaan, kultur, dan kebiasaan yang dikembangkan karena stereotipe tersebut.

3. Keputusan Orangtua memberi kesempatan Pendidikan Tinggi bagi Anak Prempuan

Mendidik anak prempuan adalah salah satu investasi terbaik yang dapat dilakukan oleh keluarga. Pendidikan berkualitas yang baik dapat mengubah hidup anak perempuan, membantu mereka mengembangkan potensi mereka sepenuhnya dan menempatkan mereka pada jalur menuju kesuksesan dalam hidup mereka. Anak prempuan yang lebih berpendidikan, misalnya, menikah nanti, memiliki anak yang lebih sehat, mendapatkan lebih banyak uang yang mereka persembahkan kembali ke keluarga.

Ada beberapa alasan dan pertimbangan yang diungkapkan oleh orangtua desa Simatorkis sehingga pada akhirnya mengambil keputusan untuk memberikan kesempatan pendidikan tinggi bagi anak-anaknya. Salah satu alasan orang tua memberikan kesempatan pendidikan tinggi anak perempuannya tidak terlepas dari keinginan untuk merubah nasib, supaya hidup anak perempuannya terjamin dan tidak merasakan kesusahan seperti yang di alami orang tuanya. Seperti yang diungkapkan oleh Yasin Siregar sebagai berikut :

"pasikolahon anaki dohot borui naporluan doi, halak nasikola do najelas masa depanna, godang harapan ku ulang songon nibaon ma 
halai jadi pakkorek, haran ni ma amben nahupasikola sampe tu parguruan tinggi"

Artinya : pendidikan itu penting sekali buat anak laki dan anak prempuan. Orang yang berilmu jelas masa depannya. Saya berharap anak saya tidak seperti saya yang menjadi penaki karet (mengguris rambong), maka saya menyekolahkan mereka sampai ke perguruan tinggi.

Seperti yang Bapak Yasin Siregar ungkapkan pentingnya pendidikan tinggi bagi anak perempuan supaya tidak mempunyai nasib yang sama dengan orang tua yang hanya berprofesi sebagai petani karet karena rendahnya pendidikan yang dimiliki dan kurangnya ketrampilan. Karena bisa dikatakan bahwa rendahnya tingkat pendidikan individu merupakan salah satu penyebab dari kondisi keluarga yang kurang mampu. Sebab bagaimanapun kemampuan sumber daya manusia yang rendah serta tidak memiki keterampilan menentukan pilihan-pilihan seseorang anak perempuan untuk bekerja pada batas kemampuannya, yaitu hanya pada sektor domestik.

Alasan lain diungkapkan oleh Jaginawan Ritonga yang memberikan kesempatan pendidikan tinggi bagi anak laki-laki maupun anak perempuannya, menyatakan sebagai berikut "alasanku pakulihon borutta ulang jadi ibu rumah tangga sajo, tai aso adong mada namalonia dohot aso marilmu ulang oto"

Artinya : Alasan anak perempuan saya kuliahkan biar tidak jadi ibu rumah tangga saja tapi biar punya kemampuan yang tinggi dan pendidikan itu bisa mengurangi kebodohan".

Jaginawan Ritonga memberikan kesempatan pendidikan tinggi kepada putrinya karena melihat lingkungan sekitar banyak ditemui contoh bahwa seseorang yang memiliki pendidikan tinggi akan memperbaiki nasibnya salah satunya adalah dengan diperolehnya 
pekerjaan yang bagus. Melihat tetangga yang lulusan strata satu itu mendapatkan jabatan dan juga pekerjaan yang tetap, dan anak yang tidak kuliah akhirnya hidupnya susah karena mendapat pekerjaan yang susah seperti buruh tani.

Lain halnya dengan Netti Rambe mengemukakan bahwa memberikan pendidikan tinggi kepada anak perempuan akan sia-sia karena pada akhirnya akan kembali ke dapur, padahal secara ekonomi Ibu Netti Rambe mampu walaupun hanya berprofesi sebagai seorang tani tapi bisa dikatakan sebagai petani yang sukses karena mempunyai lahan karet yang luas, seperti yang beliau katakan berikut

"pola hupikir pasikolahon anak daboru tu parguruan tinggi harejo na sia-sia doi, harana pola kawin cogoton ujung-ujungna tudapur do, tai anggo halak lahi tong porlu harejo harana kewajiban nia mangalehen panganon ni keluarga nia, harannii porlu kuliah aso copat dapot tia harejo"

Artinya : Saya berpikir pendidikan tinggi buat anak perempuan adalah nanti kan menjadi sia-sia karena kelak sudah menikah maka anak perempuan itu akan kembali ke dapur, tapi kalau anak laki-laki yang perlu kerja dan mempunyai kewajiban untuk menafkahi keluarga jadi perlu pendidikan yang tinggi agar mendapat pekerjaan yang mudah.

Senada dengan ungkapan oleh Nurliani Siregar (20 tahun): “ Kata Bapak, tidak ada gunanya kuliah Paman, nanti akhirnya cuma jadi ibu rumah tangga, ngurusi anak. Sebenarnya juga ingin kuliah Paman tapi berhubung bapak tidak mendukung jadi cuma sampai MA saja"

Tidak semua keluarga dapat memberikan kesempatan pendidikan tinggi kepada anak-anaknya yang disebabkan karena adanya sebuah problema (masalah) seperti keadaan ekonomi, atau kurangnya kesadaran para orang tua. Orang tua biasanya tidak 
membedakan perlakuan antara anak laki-laki dan anak perempuan tapi ketika harus membuat pilihan antara anak laki-laki dan perempuan maka pilihan orang tua jatuh pada anak laki-laki untuk mendapatkan pendidikan tinggi seperti yang diungkapkan oleh Dahlan Rambe sebagai berikut : "Sebenerna inda markapilih di au baik alak lahi bope adaboru tai biama, iba miskin haran i ma anak dalahi nadiutamahon"

Artinya : Sebenarnya saya tidak membedakan antara anak lakilaki dengan anak perempuan tapi karena keadaan ekonomi yang tidak mencukupi, dan untuk pendidikan itu yang lebih diutamakan adalah anak laki-laki.

Kesadaran terhadap gender di Desa Simatorkis terlihat dari 5 tahun terakhir hal ini terjadi karena di setiap peringatan hari-hari besar keagamaan dan nasional sedikit demi sedikit diberikan penyuluhan mengenai keseimbangan antara kedudukan perempuan dan laki-laki dalam berbagai bidang termasuk dalam bidang pendidikan. Orang tua yang beranggapan bahwa pendidikan itu tidak penting bagi anak perempuan sekarang perlahan-lahan sudah mulai berubah. Salah satu alternatif yang dilakukan oleh orang tua agar tetap bisa memberikan kesempatan pendidikan tinggi kepada anakanaknya adalah dengan memilih perguruan tinggi yang dekat dengan tempat tinggal sehingga biaya yang dikeluarkan akan sedikit.

Setelah melihat persepsi orang tua di desa Simatorkis tentang kesempatan pendidikan tinggi bagi anak-anaknya maka dapat disimpulkan bahwa sebagian dari orang tua sekarang memandang bahwa pendidikan tinggi itu penting bagi anak baik anak laki-laki maupun perempuan tanpa harus ada pembedaan.

4. Faktor yang melatarbelakangi Pendidikan tinggi Bagi Anak Prempuan di desa Simatorkis 
Dari pengamatan penulis di Desa Simatorkis bahwa kondisi sosial budaya, ekonomi dan psikologi sangat mempengaruhi mereka dalam memutuskan untuk memberi kesempatan kepada anak perempuannya dalam menempuh pendidikan tinggi. Hal tersebut selalu menjadi bahan pembicaraan dalam setiap kesempatan. a. Kondisi Sosial- Budaya

Masyarakat desa Simatorkis mengenal adat tradisi atau kebiasaan yang dilakukan secara alamiah merupakan wujud kebudayaan yang dimiliki. Secara sadar ataupun tidak sadar, kebudayaan turut mempengaruhi sikap dan pola pikir masyarakat. Perkembangan jaman, pesatnya teknologi, dan pergaulan yang luas akan mampu mengubah sedikit demi sedikit kebudayaan yang selama ini dianut oleh masyarakat Simatorkis.

Berdasarkan wawancara dengan Bapak Halomoan Rambe yang menyatakan bahwa budaya yang dulu menyatakan bahwa anak laki-laki itu lebih diprioritaskan dari pada anak perempuan tapi seiring dengan berjalannya waktu yang telah merubah pola pikir orang tua sehingga memberikan pendidikan yang sejajar dengan anak laki-lakinya.

Hal senada juga diungkapkan oleh Yusnidar Siregar : "Sekarang laki-laki atau perempuan derajatnya sama mas, perempuan jaman sekarang sudah perlu pendidikan tinggi, jadi tetap diusahakan kuliah untuk menghadapi perkembangan jaman “ Jadi kebudayaan merupakan salah satu faktor yang melatarbelakangi orang tua untuk mengambil keputusan supaya anak perempuannya melanjutkan pendidikan sampai keperguruan tinggi. Faktor kebudayaan masyarakat yang dulu menganggap bahwa pendidikan tinggi bagi seorang anak perempuan itu tidak penting sekarang sudah berubah. 
b. Kondisi Sosial Ekonomi

Dari hasil observasi dan pengamatan di desa Simatorkis kondisi sosial ekonominya bisa dikatakan menengah kebawah. Salah satu indikatornya adalah banyak dari penduduk desa Simatorkis yang mempunyai penghasilan hanya bisa memenuhi kebutuhan-kebutuhan dalam keluarga.

Pengaruh ini akan sangat terasa bagi orangtua yang kondisi ekonominya lemah. Maka orangtua harus menentukan pilihan, anak mana yang perlu diutamakan. Di desa Simatorkis anak perempuan dinomor duakan, dengan alasan anak laki-laki lebih mudah untuk bekerja dan segera dapat membantu perekonomian keluarga. Sementara anak perempuan setelah selesai sekolah malah cepat menikah, bukan bekerja untuk meringankan beban orangtua.

c. Kondisi Psikologis

Motivasi merupakan salah satu faktor psikologis yang dapat mempengaruhi anak perempuan untuk melanjutkan atau tidak melanjutkan keperguruan tinggi. Motivasi ini tidak hanya tumbuh dalam diri

anak sendiri tapi juga dapat muncul karena adanya daya penggerak dari pihak lain dalam hal ini adalah orang tua sehingga anak jadi semangat untuk meneruskan pendidikan atau tidak.

Seperti yang diungkapkan oleh Siti Jamilah Ritonga yang memperoleh kesempatan pendidikan sampai keperguruan tinggi, sebagai berikut: "saya kuliah supaya jadi serjana, dengan jadi sarjana maka mengangkat martabat keluarga menjadi lebih terpandang dan yang lebih penting dengan menjadi sarjana bisa mencari pekerjaan yang lebih baik"

Tetapi hal yang berbeda di ungkapkan oleh Risma Ritonga yang memutuskan untuk tidak kuliah. “ Buat apa tulang kuliah 
nanti paling cuma jadi ibu rumah tangga, saya menyadari kalau saya tidak pintar nanti kalau kuliah cuma buang-buang uang karena kata orang-orang kuliah itu sulit"

Selain motivasi faktor lain yang juga dapat mempengaruhi keinginan seorang anak perempuan adalah karena lingkungan keluarga. Bentuknya antara lain yaitu keinginan orang tua yang menginginkan anak perempuannya untuk memperoleh pendidikan tinggi, serta dukungan material seperti biaya pemenuhan kebutuhan dalam pendidikan. Ketika kedua dukungan tersebut tidak ada maka kecil kemungkinan bagi seorang anak perempuan untuk bisa mendapatkan kesempatan pendidikan tinggi. Seperti yang diungkapkan oleh nyonya Karti Rambe sebagai berikut: "Saya memberikan dukungan kepada anak perempuan saya meneruskan pendidikan sampai kuliah tidak hanya dalam bentuk kesempatan tapi tidak dapat dipungkiri kalau kuliah jauh dari rumah itu butuh biaya yang banyak sepert bayar kos, makan setiap harinya, keperluan lainnya, jadi saya usahakan biaya perbulan itu lancar biar anak pikirnya tidak kemana-mana dan hanya fokus kepada kuliahnya saja.

Hal yang sama dikemukakan oleh Mangboru Noman Siregar : Siapa yang tidak bangga kalau anaknya bisa kuliah, ya masalah biaya kuliah seperti transport, kos, buku, foto copy itu memang banyak, tapi bagaimana caranya tetap saya usahakan, meskipun harus berhutang.

Berdasarkan paparan diatas penulis mengetahui bahwa orang tua di desa Simatorkis seperti Kartini Rambe, Mangboru Noman Siregar sangat memberikan motivasi atau dorongan kepada anaknya untuk menempuh pendidikan yang lebih tinggi dengan 
mengusahakan biaya, meskipun mereka dalam kondisi ekonomi yang pas-pasan.

Kesadaran bahwa pendidikan tinggi merupakan kebutuhan untuk menghadapi perkembangan zaman. Masyarakat desa Simatorkis cukup menyadari bahwa pendidikan tinggi menjadikan masa depan lebih baik, baik bagi anak laki-laki maupun anak perempuan. Bila hanya menggenggam pendidikan rendah dikhawatirkan akan bernasib sama dengan orang tuanya yang ratarata hanya berprofesi sebagai petani, buruh.

\section{Penutup}

Dari sajian yang dipaparkan dapat disimpulkan bahwa kesadaran masyarakat desa Simatorkis akan pentingnya pendidikan tinggi bagi anak perempuan sudah cukup baik, hanya saja kesadaran dan keinginan untuk memberi kesempatan pendidikan tinggi kepada anak perempuan terhambat oleh kondisi ekonomi. Kesadaran pentingnya pendidikan tinggi bagi anak perempuan menandakan bahwa masyarakat Desa Simatorkis Kec. Dolok Kab. Padanglawas Utara mulai sadar akan gender. Dan tidak perlu adanya perbedaan kesempatan antara anak laki-laki dan anak perempuan. 


\section{DAFTAR KEPUSTAKAAN}

Incing, V., Hardianto, W. T., Rusmiwari, S., Studi, P., Administrasi, I., \& Tunggadewi, U. T. (2013). Kesenjangan Gender ( Perempuan ) Dalam Mendapatkan Pendidikan Pada Masyarakat Pedesaan, 2(1), 38-40.

Kaum, K., \& Millenium, M. (t.t.). Perempuan dalam Tantangan Pendidikan Global :, 8(2), 225-242.

Khayati, E. Z. (t.t.). Pendidikan dan independensi perempuan, 1-21.

Offorma, G. (2015). Girl-Child Education In Africa, (July 2009).

Pendidikan, B. (t.t.). Implementasi Kesetaraan Gender Dalam Bidang Pendidikan Warni Tune Sumar, (7), 158-182.

Shaukat, S., \& Pell, A. W. (2015). Personal and Social Problems Faced by Women in Higher Education, 9(2), 101-109.

Ihromi, Bunga Rampai Sosiologi Keluarga, Jakarta: Yayasan Obor Indonesi, 2004

Moh. Roqib, Pendidikan Perempuan, Yogyakarta: Gama Media, 2003

Mansur, Pendidikan Anak Usia Dini Dalam Islam, Yogyakarta: Pustaka Pelajar, 2014

Mansour Fakih, Analisis Gender Dan Transformasi Sosial, Yogyakarta: Pustaka Pelajar, 1996

Mansour Fakih dkk, Membincang Feminisme Diskursus Gender Perspektif Islam, Surabaya: Risalah Gusti, 1996 